\title{
THE DURATION OF OESTRUS IN OVARIECTOMIZED FINNISH LANDRACE AND SCOTTISH BLACKFACE EWES FOLLOWING PROGESTERONE AND OESTROGEN TREATMENT
}

\author{
R. B. LAND, R. THOMPSON* AND D. T. BAIRD $\dagger$ \\ Animal Breeding Research Organisation, Edinburgh EH9 $37 Q$ \\ (Received 17th May 1971, accepted 1st September 1971)
}

\begin{abstract}
Summary. The relationship between the duration of induced oestrus and the characteristics of the progesterone-oestrogen treatment used for its induction was investigated and described. The regression of the duration of oestrus on the dose of oestrogen was found to be 0.0032 and 0.0045 days $/ \mu \mathrm{g}$ in the Blackface and Finnish Landrace ewes, respectively. The duration of oestrus was also increased by approximately $40 \%$ following the division of a particular dose of oestrogen into two units given $24 \mathrm{hr}$ apart.

The mean durations of induced oestrus over all treatments, 1.52 and 1.92 days, respectively, in the Blackface and Finnish Landrace ewes, were significantly different.

It was concluded that the relationship between ewe prolificacy and the duration of natural oestrus arose at least in part from differences in the pattern of oestrogen secretion around the time of ovulation.
\end{abstract}

\section{INTRODUCTION}

An association between prolificacy and the duration of natural oestrus in the ewe has been noted in the Merino (Dunlop \& Tallis, 1964), the Lacone (Colas, 1968), and the Finnish Landrace and between the Finnish Landrace and native British breeds of sheep (Land, 1970). It was suggested that this relationship arose from differences in the pattern of steroid secretion associated with the maturation of different numbers of preovulatory follicles although it was also considered that inherent differences in sensitivity to oestrogen might exist between breeds of sheep (Land, 1970). These possibilities have now been studied indirectly by giving different progesterone-oestrogen treatments to ovariectomized Finnish Landrace and Scottish Blackface ewes and observing the duration of the subsequent induced oestrus.

\section{MATERIALS AND METHODS}

Twelve Finnish Landrace and twelve Scottish Blackface ewes of similar ages (range 2 to 8 years) were ovariectomized in autumn 1969. Steroid treatments

* Present address: A.R.C. Unit of Statistics, Edinburgh.

$\uparrow$ Present address: Department of Obstetrics and Gynaecology, University of Edinburgh. 
were started in January 1970, each treatment consisting of a series of single intramuscular progesterone (Protormone, Burroughs Wellcome Ltd) injections on treatment Days 1 to 5 followed by an intramuscular injection of oestrogen (oestradiol-17 $\beta$ ) on Day 7 or Days 7 and 8. The doses consisted of the following alternatives: (1) 10 versus $20 \mathrm{mg}$ progesterone/day; (2) 40 versus $60 \mu \mathrm{g}$ unit doses of oestrogen, which were given, (a) as a single unit injection on Day 7 , (b) as a double unit injection on Day 7 (i.e. twice the basic dose given at a single injection), and (c) as twin unit injections on Days 7 and 8 (i.e. twice the basic dose, the single injection being repeated a day later). In this way, it was possible (i) to consider the effects of a twofold increase in the basic unit doses (40 and $60 \mu \mathrm{g}$ ), given either as a double dose on the single occasion or as twin doses given over 2 days, and (ii) to consider the progression from 40 to 60,80 and $120 \mu \mathrm{g}$ of oestrogen, given as a single injection. All injections were made up to $2 \mathrm{ml}$ with ethyl-oleate and were given intramuscularly.

Oestrus was determined by the introduction of vasectomized rams at 16.00 hours on Day 7, and subsequently at 09.00 and 16.00 hours daily until the end of oestrus, or 09.00 hours on Day 10. Each positive identification of oestrus, therefore, represented a period of half a day. Each cycle of treatment and oestrus detection took 21 days, and was repeated twelve times. Within each breed, a latin square design was used so that all twelve treatments were used in each of the twelve cycles, and given to each ewe during the course of the cycles.

During the first four cycles (Day 1, Cycle 1=6-1-70), Finnish Landrace rams only were used for the detection of oestrus, whereas during the last eight cycles (Day 1, Cycle $5=30-6-70$ ), the results of teasing with Finnish Landrace and Scottish Blackface rams were recorded separately.

All twenty-four ewes and the rams used for the detection of oestrus were kept outdoors at the Animal Breeding Research Organisation Field Laboratory, Roslin, Midlothian, throughout the experiment. Grazing was supplemented by both hay and concentrates during the winter.

\section{RESULTS}

The duration of oestrus in both breeds of ewe was first considered as that determined by teasing with the Finnish Landrace rams, and the mean values for each of the twelve treatment combinations given in Table 1 for both breeds of ewe together with a summary of the analyses of variance arising from the factors studied. It can be seen that, within both breeds, the duration of oestrus was greater $(P<0.05)$ following treatment with 10 than with $20 \mathrm{mg}$ of progesterone and that there was no interaction between the dose of progesterone and the subsequent oestrogen treatments. Oestrogen comparisons were therefore made on the average over the two doses of progesterone. In addition, it can be seen that there were no residual effects from one cycle of treatment to the next.

In both breeds, a twofold increase in the total dose of oestrogen increased the duration of oestrus from a mean of 1.21 days following treatment with a single unit, to 1.68 days following double and twin units in the Blackface ewes. The corresponding means for the Finnish Landrace ewes were 1.51 and 2.17 days, both increases being statistically significant $(P<0 \cdot 01)$. This effect was mainly 
due to the fact that, within the high doses, the duration of oestrus was greater when the dose was given as twin injections over 2 days than when it was given as a single injection $(P<0.01)$. The magnitude of this effect was similar in both breeds, the duration of oestrus being $38 \%$ and $43 \%$ greater following twin relative to double injections in the Finn and Blackface ewes, respectively.

TABLE 1

THE DURATION OF OESTRUS IN OVARIECTOMIZED FINNISH LANDRACE AND SCOTTISH BLACKFACE EWES FOLLOWING DIFFERENT PROGESTERONE-OESTROGEN TREATMENTS AND THE MEAN SQUARES FROM ANALYSES OF VARIANCE ARISING FROM THESE TREATMENTS

\begin{tabular}{|c|c|c|c|c|c|c|c|}
\hline \multirow[b]{3}{*}{ Progesterone: } & \multirow{3}{*}{ Oestrogen } & \multicolumn{6}{|c|}{ Mean duration of oestrus (days) } \\
\hline & & \multicolumn{3}{|c|}{ Blackface } & \multicolumn{3}{|c|}{ Finn } \\
\hline & & 10 & 20 & Mean & 10 & 20 & Mean \\
\hline Single & $\begin{array}{l}40 \\
60\end{array}$ & $\begin{array}{l}1.50 \\
1.63\end{array}$ & $\begin{array}{l}0.84 \\
0.88\end{array}$ & $\left.\begin{array}{l}1.17 \\
1.25\end{array}\right\} 1.21$ & $\begin{array}{l}1 \cdot 71 \\
1 \cdot 58\end{array}$ & $\begin{array}{l}1 \cdot 33 \\
1.42\end{array}$ & $\left.\begin{array}{l}1.52 \\
1.50\end{array}\right\} 1.51$ \\
\hline Double & $\begin{array}{l}40 \\
60\end{array}$ & $\begin{array}{l}1.46 \\
1.75\end{array}$ & $\begin{array}{l}1 \cdot 17 \\
1 \cdot 12\end{array}$ & $\left.\begin{array}{l}1.31 \\
1.44\end{array}\right\} 1.38$ & $\begin{array}{l}1.88 \\
1.96\end{array}$ & $\begin{array}{l}1.58 \\
1.71\end{array}$ & $\left.\begin{array}{l}1.73 \\
1.84\end{array}\right\} 1.78$ \\
\hline Twin & $\begin{array}{l}40 \\
60\end{array}$ & $\begin{array}{l}1.92 \\
2 \cdot 04\end{array}$ & $\begin{array}{l}2.04 \\
1.92\end{array}$ & $\left.\begin{array}{l}1.98 \\
1.98\end{array}\right\} 1.98$ & $\begin{array}{l}2.58 \\
2 \cdot 58\end{array}$ & $\begin{array}{l}2 \cdot 42 \\
2 \cdot 25\end{array}$ & $\left.\begin{array}{l}2.50 \\
1.42\end{array}\right\} 2.46$ \\
\hline Mean & & 1.72 & 1.33 & 1.52 & $2 \cdot 05$ & 1.78 & 1.92 \\
\hline $\begin{array}{l}\text { Standard error of a single } \\
\text { combination mean }\end{array}$ & & & $0 \cdot 224$ & & & 0.219 & \\
\hline
\end{tabular}

Analyses of Variance

\begin{tabular}{|c|c|c|c|}
\hline Source & d.f. & $\begin{array}{c}\text { Blackface } \\
\text { M.S. }\end{array}$ & $\begin{array}{l}\text { Finn } \\
M . S .\end{array}$ \\
\hline $\begin{array}{l}\text { Between sheep } \\
\text { Between cycles } \\
10 \text { versus } 20 \mathrm{mg} \text { progesterone } \\
40 \text { versus } 80 \text { (double and twin) } \mu \mathrm{g} \text { oestrogen } \\
60 \text { versus } 120 \text { (double and twin) } \mu \mathrm{g} \text { oestrogen } \\
\text { Double } 40 \mu \mathrm{g} \text { versus twin } 40 \mu \mathrm{g} \text { oestrogen } \\
\text { Double } 60 \mu \mathrm{g} \text { versus twin } 60 \mu \mathrm{g} \text { oestrogen } \\
40 \text { versus } 60 \mu \mathrm{g} \text { oestrogen (single +double }+ \text { twin) } \\
\text { Oestrogen } \times \text { progesterone interactions } \\
\text { Residual effects } \\
\text { Error }\end{array}$ & $\begin{array}{r}11 \\
11 \\
1 \\
1 \\
1 \\
1 \\
1 \\
1 \\
5 \\
11 \\
99\end{array}$ & $\begin{array}{l}1 \cdot 672 \\
5 \cdot 063 \\
5 \cdot 444 \\
3 \cdot 674 \\
3 \cdot 361 \\
5 \cdot 333 \\
3 \cdot 521 \\
0 \cdot 174 \\
0 \cdot 728 \\
0 \cdot 110 \\
0 \cdot 601\end{array}$ & $\begin{array}{l}3 \cdot 174 \\
2 \cdot 625 \\
2 \cdot 507 \\
5 \cdot 641 \\
6 \cdot 250 \\
7 \cdot 130 \\
4 \cdot 083 \\
0.000 \\
0.045 \\
0 \cdot 345 \\
0.577\end{array}$ \\
\hline
\end{tabular}

Duration of oestrus determined by teasing with vasectomized Finnish Landrace rams.

Consideration of the results in terms of the duration of oestrus following either a single unit injection of oestrogen, a single injection of a double unit or two injections of the single unit $24 \mathrm{hr}$ apart, suggests that the duration of oestrus is increased following a doubling of the dose of oestrogen, and also that this increase is greater when the higher dose is given as two injections.

The relationship between the duration of oestrus and the dose of oestrogen given on a single occasion was examined specifically by regressing the duration of oestrus on the dose of oestrogen given as a single or double unit. The regression coefficients were $0.0032 \pm 0.0027$ and $0.0045 \pm 0.0026$ days $/ \mu \mathrm{g}$ in the Blackfaces 
and Finns, respectively. This represents a mean increase of $6 \cdot 1 \pm 5 \cdot 2$ and $8 \cdot 6 \pm$ $5.0 \mathrm{hr}$ of oestrus in the Blackface and Finn females, respectively, as the dose of oestrogen was increased from 40 to $120 \mu \mathrm{g}$. In both breeds, therefore, there was an increase in the duration of oestrus as the dose of oestrogen increased, the greater rate of increase and higher mean values observed for the Finn not differing significantly $(P>0.05)$ from those observed for the Blackfaces.

The comparison of the two breeds can be considered further by examining their mean response over all treatments and comparing the duration of oestrus as determined by Finn and Blackface rams during the last eight cycles of treatment. The mean duration of oestrus (as determined by vasectomized Finn rams) over all cycles and for all treatments was 1.52 days and 1.92 days for the Blackface and Finn rams, respectively (Table 1). The between-sheep mean squares show that this difference is statistically significant $(P<0 \cdot 05)$. The duration of oestrus as determined by Finn rams is therefore greater in Finn than in Blackface ewes. A comparison of the total number of positive identifications of oestrus by the Finn and Blackface rams for the two breeds of ewe during the last eight cycles, however, reveals that the Blackface rams made $5.3 \%$ fewer positive identifications of oestrus in the Finn females than did the Finn rams, but $7 \cdot 2 \%$ more positive identifications of oestrus in Blackface females than did the Finn rams. In both cases, the use of the same breed of ram resulted in an increase in the number of positive identifications of oestrus. These differences did not arise at the same time of the year, the Finn male-Finn female score exceeding that of the Blackface male-Finn female in the summer (9th July to 16th September) whereas the Blackface male-Blackface female score exceeded that of the Finn male-Blackface female in the autumn and winter (8th October to 9th December), $(P<0.05)$. The longer mean duration of oestrus recorded by Finn rams for Finn ewes relative to Blackface ewes may, therefore, be partly the result of preferential assortative mating, the extent of which is dependent upon seasonal changes in male libido.

\section{DISCUSSION}

The results of this experiment demonstrate the existence of a strong relationship between the duration of oestrus in the present breeds of progesterone-pretreated ovariectomized sheep and the dose of oestradiol-17 $\beta$ used to induce oestrus. This correlation was not only present in the two breeds of sheep studied, but the quantitative relationships between the duration of oestrus and the dose of oestrogen used were of a similar order of magnitude, despite the differences in their natural prolificacy (Donald \& Read, 1967; Wiener, 1967) and duration of natural oestrus (Land, 1970). A similar relationship has recently been observed in Border Leicester $\times$ Merino ewes in Australia (Fletcher \& Lindsay, 1971; Scaramuzzi, Lindsay \& Shelton, 1971).

A comparison of the observed mean increase in the duration of oestrus of $3.65 \mathrm{hr}$ as the dose of oestrogen is increased from 40 to $80 \mu \mathrm{g}$ and from 80 to $120 \mu \mathrm{g}$ with an increase in the duration of oestrus within Finnish Landrace females of $2.9 \mathrm{hr} /$ extra lamb born (calculated from data presented by Land, 1970) indicates that the within-breed correlation between the duration of oestrus at 
mating and the number of lambs subsequently born probably stems from a higher rate of oestrogen secretion by the more prolific ewes. This indication is strengthened by the observation that the duration of oestrus is reduced by an increase in the dose of progesterone; any differences in progesterone secretion during the luteal phase of the oestrous cycle would therefore be expected to decrease the duration of oestrus of the more prolific ewes.

In the present experiments, an increase of $31.8 \mu \mathrm{g}$ in the dose of oestrogen provoked an increase in the duration of oestrus which was similar to that previously observed to be associated with the birth of an extra lamb. Moreover, the injection of two basic units of oestrogen 1 day apart resulted in a mean increase in the duration of oestrus which was approximately $40 \%$ greater than that observed when the two basic units were given as a single injection.

The demonstration of a relationship between the duration of induced oestrus and the characteristics of the previous oestrogen treatment does not exclude the possible existence of between-breed differences in hypothalamic sensitivity to oestrogen. Although the present observation of such a breed difference may have been partly the result of positive assortative mating, as has been observed in a competitive situation (Lees \& Weatherhead, 1970), there is still a strong indication that the Finnish ewes were more sensitive to oestrogen than were the Blackface ewes. Such a differential sensitivity would not, however, be sufficient to account for all the between-breed and cross-breed differences previously observed.

The present experiment has enabled us to conclude that both the within- and between-breed relationships of ewe prolificacy with the duration of natural oestrus arise, at least in part, from the association of litter sizes with the development of more follicles and a different pattern of oestrogen secretion. It may, therefore, be possible to consider estimates of both gonadotrophic activity as suggested by Land (1971) and oestrogen secretion for the characterization and selection of sheep for improved reproductive performance.

\section{ACKNOWLEDGMENTS}

We wish to thank Mr A. D. Macgregor, Mr G. Davidson and Mrs H. F. Kelly for experimental assistance and Mr A. Littlejohn of the Royal (Dick) Veterinary College for the ovariectomy of the experimental animals. This work was supported in part by a grant from the Medical Research Council to D.T.B.

\section{REFERENCES}

Colas, G. (1968) Durée de l'oestrus et fertilité après insémination artificielle chez la brebis. VIth Int. Cong. Reprod. Anim. Insem. Artif., Paris, 2, 1017.

Donald, H. P. \& ReAd, J. L. (1967) The performance of Finnish Landrace sheep in Britain. Anim. Prod. 9, 471 .

Dunlop, A. A. \& TAllis, G. M. (1964) The effects of length of oestrus and number of inseminations on the fertility and twinning rate of the Merino ewe. Aust. F. agric. Res. 15, 282.

FLETCHeR, I. C. \& LiNDSAY, D. R. (1971) Effects of oestrogen on oestrous behaviour and its variation with season in the ewe. 7 . Endocr. 50, 685 .

LAND, R. B. (1970) A relationship between the duration of oestrus, ovulation rate and litter size of sheep. F. Reprod. Fert. 23, 49. 
LAND, R. B. (1971) The incidence of oestrus during lactation in Finnish Landrace, Dorset Horn and Finn-Dorset sheep. 7. Reprod. Fert. 24, 345.

Lees, J. L. \& Weatherhead, M. (1970) A note on mating preferences of Clun Forest ewes. Anim. Prod. $12,173$.

Scaramuzzi, R. J., Lindsay, D. R. \& Shelton, J. N. (1971) The effects of oestradiol benzoate on the duration of oestrous behaviour in the ovariectomised ewe. 7 . Endocr. 50, 345.

Wiener, G. (1967) A comparison of the body size, fleece weight and maternal performance of five breeds of sheep kept in one environment. Anim. Prod. 9, 177. 